\title{
PLURALISME AGAMA DAN MODERNITAS PEMBANGUNAN
}

\author{
Burhanudin Mukhamad Faturahman \\ E-mail : burhanmfatur@gmail.com \\ Ilmu Administrasi Universitas Brawijaya
}

\begin{abstract}
ABSTRAK
Konflik sosial yang terjadi di Indonesia dengan latar belakang agama sangat memprihatinkan. Pluralisme agama seharusnya menjadi tolok ukur toleransi antar umat beragama di tengah keberagaman kepercayaan dengan sikap toleran, berkeadilan dalam rangka menuju civil society. Selain itu modernitas disinyalir merusak tatanan sosial karena menciptakan sistem ekonomi yang tidak adil. Tujuan penulisan ini untuk membahas pluralisme agama beserta nilai yang terkandung didalamnya ditinjau dari pemikiran Dawan Rahardjo, Nurcolish Madjid dan John Hick beserta kontribusi modernitas terhadap timbulnya konflik sosial. Hasil penelitian yaitu pluralisme agama di Indonesia menurut Rahardjo disikapi sebagai integrasi sosial sebagai dasar berperilaku karena sebenarnya agama-agama mengajarkan nilai-nilai kebajikan umum sedangkan Madjid berpandangan civil society adalah rumah dari demokrasi dengan etika masyarakat sebagai kualitas dari kehidupan demokrasi. Hick menyatakan pluralisme sebagai keterpusatan pada diri sendiri menuju keterpusatan pada sang Realitas tunggal (Tuhan) melalui berbagai bentuk dan cara. Keberagaman ini rentan konflik karena modernitas memicu terjadinya kemiskinan, rusaknya lingkungan dan kekerasan komunal. Oleh karena itu penguatan pendidikan multi agama dan etika global pada perguruan tinggi mutlak dilaksanakan sebagai upaya menciptakan civil society.
\end{abstract}

\section{Kata kunci: pluralisme, modernitas, etika, civil society}

\begin{abstract}
ABSTRACK
Social conflict that occurred in Indonesia with a religious background is very concern. Religious pluralism should be the yardsticks religious tolerance in the midst of diversity, tolerant attitude of trust with fairness in order toward a civil society. In addition modernity allegedly subverts the social order because it creates an unfair economic system. The purpose of this writing to discuss religious pluralism with the value contained in it in terms of thinking Dawan Rahardjo, Nurcolish Madjid and John Hick with a contribution of modernity against the onset of social conflict. The research of religious pluralism in Indonesia namely according to Rahardjo addressed as a social integration as the Foundation behave because actual religions taught the values of public virtue while Madjid argued civil society is Home of democracy with an ethic of community as the quality of the life of democracy. Hick States pluralism as centering yourself towards the single reality of centering (of God) through different forms and ways. This diversity is vulnerable to conflict because of modernity triggered poverty, environmental destruction and communal violence. Therefore strengthening the education of multi religious and ethical global College absolutely implemented in an effort to create a civil society.
\end{abstract}

\section{Keywords: pluralism, modernity, ethics, civil society}




\section{PENDAHULUAN}

Perdebatan mengenai fenomena pluralitas dalam kehidupan berbangsa dan bernegara selalu menarik untuk dikaji. Fatwa Majelis Ulama Indonesia (MUI) tentang keharaman pluralitas pada tahun 2005 yang menyamakan pluralitas dengan liberalisme dan sekularisme memberikan respon kritis di kalangan intelektual muslim terhadap fatwa tersebut. Terdapat banyak tulisan yang sangat kritis untuk pemaknaan pluralitas sempit tersebut diantaranya $\mathrm{M}$. Dawam Rahardjo: Mengapa Semua Agama Itu Benar? (2006), Martin Lukito Sinaga: Agama Tanpa Sosiologi Agama, Meninjau Wacana Pluralisme di Indonesia (2006), Trisno S. Susanto: Membaca (kembali) Poliltik Pluralisme, Catatan untuk Martin Lukito Sinaga (2006). Kedua tulisan ini mengkritisi fatwa pluralisme oleh MUI yang miskin perspektif dan memantik kontroversi. Sedangkan tulisan Rahardjo, menurutnya dalam mengadapi keberagaman kita membutuhkan pluralisme. Konsekuensinya yaitu jika satu pihak menerima pluralitas sebagai realitas sedangkan pihak lain menolak pluralisme sebagai suatu paham.

Indonesia sarat dengan pluralitas dan pluralisme terutama yang terkait dengan agama sebagai takdir dan selalu berada dalam posisi problematis. Menurut salah satu teori sejarah, Islam datang ke bumi nusantara pada abad ke-7 M akan tetapi Islam tidak memasuki ruang hampa. Jauh sebelum datangnya Islam, masyarakat Nusantara telah terpola ke dalam berbagai agama dan kepercayaan. Agama-agama lainnya pun berdatangan. Dalam versi negara, pada saat ini ada enam agama yang diakui eksistensinya, yaitu: Islam, Kristen, Katolik, Hindu, Budha, dan Konghucu. Sisi problematis dari keragaman tersebut adalah adanya potensi konflik. Pertanyaan pentingnya mengapa agama dapat menimbulkan konflik?. Ini terdengar aneh karena ajaran agama apapun selalu menekankan pada kesamaan dan kesetaraan manusia. Ini merupakan visi perenial semua agama. Potensi konflik keragaman agama yang demikian ini berada di luar wilayah perenial agama, lebih banyak terjadi pada wilayah konstruksi sosial.

Mengapa wilayah ini rentan konflik? Konstruksi merupakan modus yang dikembangkan oleh seseorang dalam memahami doktrin agama. Agama memang meniscayakan pada suatu modus pemahaman agar kehendak Tuhan yang terdapat dalam doktrin agama bisa dipahami dan dilaksanakan oleh pengikutnya yang dimuat dalam AlQur'an, Injil, dan kitab-kitab lainnya. Dalam menjembatani aktualisasi nilai-nilai dalam kitabkitab tersebut maka diperlukan pemahaman manusia. Jadi, tidak mungkin beragama tanpa didasari oleh konstruksi. Tetapi, hasil konstruksi manusia terhadap agama tidaklah tunggal (pluralitas internal) pada akhirnya tidak bisa dihindari. Maka berkembanglah berbagai macam mazhab pemikiran dalam agama tertentu. Dari perbedaan mazhab pemikiran lalu berkembang menjadi perbedaan kelompok dalam suatu organisasi. Karena berkembang menjadi suatu organisasi, maka agama pun terbawa hubungan antar organisasi.

Konstruksi tidak hanya menimbulkan masalah dalam lingkup internal agama saja misalnya antara Sunni dan Syiah dalam Islam. Konstruksi tersebut juga berpengaruh terhadap agama lain, katakanlah antara Hindu dan Islam, Islam dan Kristen, Budha dan Hindu dan seterusnya. Masing-masing (konstruksi) agama selalu ada keinginan membandingkan antara agama sendiri dengan agama lain yang kemudian berujung pada suatu klaim kebenaran (truth claim) terhadap keunggulan dalam hal otentisitas agamanya sendiri. Sebaliknya, jika pemahaman pluralitas tersebut dimaknai sebagai relaitas dan juga paham maka sikap toleransi beragama sangat mungkin diciptakan. Menurut Rosyid (2014) keselarasan beda agama dan 
aliran di Kudus merupakan cerminan pluralitas antara Nahdliyin, Kristiani, Buddhis, dan Ahmadi. Kerukunan terwujud karena adanya kesadaran akan kesamaan aspek budaya. Selain itu, mayoritas ekonomi masyarakat pada skala sedang (tidak miskin) sehingga tidak mudah tersulut konflik, tidak adanya loko pemicu konflik. Terakhir, adanya ikatan kekeluargaan dan keakraban dalam kehidupan sosial antar dan intern-pemeluk agama dan aliran.

Hidup dalam nuansa pluralitas merambah bidang bidang lainnya meliputi bidang ekonomi, sosial maupun bidang lain yang berpotensi. Kasus penistaan agama yang dilakukan Ahok saat berbicara di Kepulauan Seribu tanggal 27 September 2016 yang mengutip ayat Alquran surat Al-Maidah ayat 51 memberikan sinyalemen bahwa hukum juga harus bertindak secara tegas dan responsif. Menurut Kombes Heri, Polisi sudah menetapkan Ahok menjadi Tersangka dalam hal Penistaan Agama tersebut dan melanggar pasal 156 KUHP dan atau Pasal 156a KUHP dan UU ITE tetapi jaksa tidak memakai UU ITE dalam Dakwaannya. Lebih hanya kepada kedua pasal tersebut dalam Surat Edaran Kapolri tentang Ujaran Kebencian SE/06/X/2015 (Akbar, 2017).

Memudarnya sikap intoleransi merupakan dampak dari sikap fanatik dibingkai dalam klaim kebenaran absolut. Dalam klaim kebenaran sebenarnya terjadi pembatasan (teritorialisasi) secara rigit antara pemahaman yang benar dan yang salah. Sebagaimana yang terjadi dalam pembatasan yang bersifat geografis, pembatasan dalam wilayah agama juga ditandai dengan adanya sikap protektif dan konservatif agar wilayah (pemahaman) yang dianggap salah, tidak merusak wilayah yang benar. Oleh karena itu, terdapat persyaratan yang ketat untuk memasuki dan diakui sebagai bagian pemahaman yang benar selanjutnya menurut Esack (1997) membentuk sikap konservatisme. Jika terjadi terhadap kaum Muslim, konservatisme ditandai semakin sempitnya basis teologis dalam mendefinisikan iman, Islam, dan memperluas basis bagi kufur sehingga semakin sedikit yang dianggap beriman dan makin banyak yang digolongkan kafir. Lebih ekstrim membuat jarak dengan kelompok atau agama lain semakin lebar.

Semakin renggangnya jarak sosial sangat mengancam keutuhan kehidupan (disintegrasi) berbangsa dan bernegara dalam rangka mencapai mencapai tujuan-tujuan politik, sosial, dan ekonomi mencakup peningkatan kesejahteraan hidup, keadilan sosial dan rasa aman bagi setiap anggota masyarakat (human security). Untuk mencapai tujuan tersebut maka usaha modernisasi, pembangunan, demokratisasi dan pembaharuan ekonomi. Pertanyaan penting yang harus dijawab apakah model pembangunan yang selama ini dilakukan oleh pemerintah Indonesia sudah berkontribusi dalam meningkatkan kesejahteraan serta menciptakan rasa aman masyarakat ?. Sementara itu di beberapa daerah yang dilanda konflik seperti Aceh dan Papua rakyat kecil semakin kehilangan rasa aman karena menjadi korban akibat konflik negara dengan kelompok separatis.Sumandoyo (2015), Konflik di Aceh dilatar belakangi masalah kekuasaan dimana terdapat perbedaan kepentingan politik siapa menguasai siapa, kepentingan ekonomi sehingga mengakibatkan konflik. Meskipun secara formal sudah tuntas tetapi pembangunan dan proses politik di Aceh tidak menguntungkan bagi rakyat banyak. (Asad Said Ali, 2015 merdeka.com).

Sedangkan konflik di Papua terjadi karena pendekatan ekonomi dan kesejahteraan termasuk pendekatan agama tidak dilakukan. Papua terdapat banyak gereja katolik, protestan notabene nasionalis. Ada 2 (dua) syafaat yang dianut, sebagian (gereja) yang baru disetir dari 
luar negeri dan perlu diingatkan bagaimana pentingnya berbangsa. Gereja pun harus menumbuhkan jiwa nasionalisme. Boleh menerima bantuan dari luar negeri akan tetapi harusa ada filter untuk kepentingan bangsa dan negara (Asad Said Ali, 2015 merdeka.com). Aceh dan Papua yang kaya akan sumberdaya alam ternyata menjadi kantong-kantong kemiskinan yang kemudian melahirkan tindak kekerasan sebagai senjata untuk melawan ketidakadilan sosial. Hingga kini kasus seperti terorisme masih marak terjadi. Serangkaian ledakan yang terjadi di tiga area Gereja di Surabaya bulan Mei 2018, yakni, Gereja Katolik Santa Maria Tak Bercela, GKI dan Gereja Pantekosta disusul dengan ledakan bom di Mapolrestabes Surabaya hari esoknya membuat ancaman disintegrasi bangsa semakin nyata.

Pluralisme di Indonesia bukan saja dimaknai sebagai keberagaman entitas antar agama, budaya, etnis semata namun makna tersebut dipahami sebagai perwujudan keshalehan sosial. Di sisi lain, pluralitas itu sendiri berpotensi menjadi bencana sosialketika ketimpangan pembangunan masih terjadi. Ketimpangan yang tinggi juga menyulut aksi radikalisme dan terorisme.Ketimpangan tinggi terdapat di 8 kota dengan gini rationya di atas tingkat nasional. Gini ratio tertinggi berada di kota Yogyakarta sebesar 0,425, Gorontalo 0,410, Jawa Timur 0,402, Jawa Barat 0,402, Papua Barat 0,401, Sulawesi Selatan 0,400, Papua 0,399, dan Jakarta sebesar 0,397 (kumparan.com, 2017). Berangkat dari permasalahan yang telah diuraikan bahwa modernisasi merupakan salah satu upaya pembanguan menuju kesejahteraan dan keamanan sosial mengandung resiko cukup tinggi yang harus diantisipasiTujuan daripada penulisan ini yaitu memahami pluralitas beragama sebagai pemahaman dan relevansi modernisasi pembangunan dalam menjaga kemanan sosial.

\section{METODE PENELITIAN}

Peneliti menggunakan penelitiankepustakaan, yakni mengkaji sejumlah bahan pustaka yangbertujuan untuk mendeskripsikan dan ataumerekonstruksi fenomena-fenomena sosial tertentusecara obyektif dan akurat. Bahan-bahan kepustakaan yang dikaji adalah pemikiran Nurcholish Madjid, M. DawamRahardjo dan John Hick. Dua tokoh pertama memiliki perhatian yangbesar terhadap perkembangan wacana pluralismedi Indonesia. Sedangkan John Hick adalah salah satu pemikirmodern yang berbasis filsafat serta mengedepankan pentingnyaperdamaian dalam kritisismenya terhadap teologi agama-agama. Permasalahan modernitas pembangunan juga turut dikaji karena modernisasi turut memberikan kontribusi konflik di negara sedang berkembang khususnya Indonesia.

\section{HASIL DAN PEMBAHASAN}

\section{Wacana Rekonstruktif Pluralisme}

Pemikiran keagamaan di Indonesiaselama dasa warsa terakhir ini mengalami perkembangan positif. Hal ini dapat dilihat begitu banyaknya kajian-kajian keagamaan yang dilakukan olehsejumlah pusat-pusat kajian. Sementara itu, kajian keagamaan dilembaga konvensional seperti perguruan tinggi memperlihatkanperkembangan yang tidak kalah menariknya. Berkembangnya kajian oleh M. Amin Abdullah disebut dengan aspekhistorisitas agama, setelah sebelumnya lebihdidominasi oleh kajian terhadap aspek normatif agama. Pergeseran titik perhatian ini, memiliki pengaruh yang sangat besarterhadap pendekatan yang 
digunakan dalammengkaji agama baik dipusat-pusat kajian non konvensional, maupunkonvensional, pendekatan dalam ilmu-ilmu sosialmulai sering digunakan sehingga kajian ilmu sosial dan keagamaan saling menguatkan.

Dari segi subyek kajian, pluralitas agama memprolehperhatian yang cukup besar di samping aspeksosial keagamaan lainnya. Persoalankemajemukan ini penting untuk diperhatikan karena dua hal yakni pertama, faktakemajemukan agama di Indonesia besertapermasalahannya yang begitukompleks. Kedua, terkait masa depan hubungan antar umat beragama diIndonesia. Kajian pluralitas agamabukanlah hal baru di Indonesia karenapada tahun 1961 di IAIN Yogyakarta membuka jurusan Perbandingan Agama di bawah pembinaan A. Mukti Ali.Jika diabndingkan dengan kajian periode sebelumnya, penekanan kajian kemajemukan pada tahun 90-an lebih pada upaya untuk mencari titiktemu (modus vivendi) antara agama yang satu dengan agama lain melalui pendekatan dialogis. Pendekatan ini mendapat porsi yang besar pada saat itu. Pad saat yang sama, tahun 90-an kejadian beruntun konflik memusatkan pada aspek perbedaan agama. Dan sampai saat ini konflik tersebut terusberlanjut. Fakta inilah, kajianterhadap kemajemukan agama di Indonesia perlu terusdikembangkan.

Abdullah (1995) menyatakan bahwa pertimbangan secara objektif terhadap kemajemukan di Indonesia serta membandingkannya dengan berbagai situasi dan kondisi politik luar negeri, studi agama (religious studies) di Indonesia terasa sangat penting dan mendesak untuk dikembangkan. Hal tersebut diperparah dengan munculnya kerusuhan di berbagai wilayah di Nusantara dipicu faktor agama.Jika tidak diperhatikan secara serius, bisa merusaktatanan harmoni di kalangan umat beragamayang selama ini terpelihara, akibat selanjutnya yaiturusaknya stabilitas nasional. Studi danpendekatan agama yang bersifatkomprehensif, multidisipliner, interdisiplinerdengan menggunakan metodologi yangbersifat historis-kritis. Metodologi tersebut melengkapi metodologi yang bersifatdoktriner-normatif merupakan pilihan yang tepatuntuk masyarakat Indonesia yang begitumajemuk.

Menciptakan ruang dialog antar agama bukan hal yang mudah. Kendala itu justru disebabkan cara berpikir agama yang kurang kritis. Akar konflik teologis menurut D'adamo dalam Arifin (2009) adalah berawal dari sebuah standar tentang agamanya sendiri -kitab sucinya- merupakan sumber kebenaran yang sepenuhnya diyakini. Pandangan D'adamo tentang standar ganda:

1. Bersifat konsisten dan berisi berbagai kebenaran tanpa kesalahan sama sekali.

2. Bersifat lengkap dan final. Oleh karenanya kebenaran dari agama lain tidak diperlukan.

3. Menyakini agama sendiri sebagai satu-satunya jalan keselamatan, pencerahan atau pembebasan.

4. Menyakini bahwa seluruh kebenaran itu diyakini berasal dari Tuhan tanpa konsttruksi manusia.

Sikap semacam ini masih sarat dengan teologi formal tradisional. Teologi formal tradisional (Said,2005) kurang memberikan sentuhan yang berarti untuk mengikuti perkembangan ilmu-ilmu sosial dan historisitas keagamaan yang tidak bisa dilepaskan dari 
tradisi sejalan dengan ruang dan waktu yang membingkainya. Perspektif berpikirnya terus berputar-putar di wilayahnya sendiri dan kurang menyentuh teologi keagamaan lainnya. Teologi yang terbangun kurang memiliki ruang bagi orang lain untuk dapat menanggapi teologi yang dianutnya. Sehingga teologi keagamaan tidak punya komitmen terhadap nilainilai kemanusiaan universal sebagaimana teologi yang diusung teror serta konflik horizontal dengan faktor keagamaan sebagai pemicunya.

\section{Genealogi Pluralisme Agama}

Secara terminologi pluralisme merupakan sebuah paham tentang kemajemukan bahwasannya kehidupan yang majemuk haruslah ditata untuk menciptakan suasana saling menghargai dan menghormati guna menghindari konflik (wikipedia.com). Paham pluralisme ini menyangkut kehidupan dalam masyarakat berkembang ke ranah teologi (keagamaan) dimana makna ini lebih dalam daripada makna secara sosiologis dan filsafat.

Pluralisme dalam ranah teologis ditengarai memiliki hubungan denganpemikiran filsafat yang menandai lahirnya zaman baru yang disebut post-modern di barat. Kesadaran paham tersebut lahir dari kalangan gereja melalui Konsili Vatikan II tahun 1962 sampai dengan tahun1965. Pengakuan bahwa Kristen bukan satu-satunya kebenaran di dunia telah meciptakan plural shock (kejutankemajemukan). Menurut Darmaputra (1987) agama Kristen berkeinginan menjadi agama satu-satunya yang benar. Namun fenomena menunjukkan terdapat agama-agama lain yang tumbuh subur sehingga mengharuskan agama Kristen hidup berdampingan dengan ajaran kebenaran dari agama lain yang tidak dapat dipandang sebelah mata. Dengan demikian model plural shockadalah keharusan sejarah, dan bagi mereka yang bersikukuh menginginkan ajarannya paling benar akan tercabut dari realitas dan menjadi usang serta tidak relevan lagi.

Arif (2010) mengungkapkan bahwa pluralismeagama-agama di dunia merupakan persenyawaan tiga tesis. Pertama, memiliki tradisi yang sama, semuanya merujuk danmenunjuk realitas tunggal yang transendental dan suci.Kedua, sama-sama menawarkan jalan keselamatan.Ketiga, tidak ada yang bersifat final artinya setiap agamaselalu terbuka untuk dikritik dan ditinjau kembali. Paham pluralisme hadir karena paham yang dianut keagamaan condong ke arah eksklusifime dan inklusifisme. Paradigma eksklusifisme mengajarkan keselamatan hanya ditujukan pada pengikut agama tertentu saja yang membentuk karakter fundamentalis (agama lain perlu ditaklukkan). Sedangkan paradigma inklusifisme mengajarkan bahwa keselamatan suatu agama berlaku secara universal. Dalam Agama Kristen, terdapat istilah "Kristen tanpa nama". Inklusivisme berusaha memadukan dua pengakuanteologis: adanya keselamatan agama-agama lain dan keunikan Tuhan dalam agama yang dianutnya namun paham ini dinilai masih sarat dengan normatif karena memandang rendah agama lain. Hick (1995) kemudian mengedepankan pluralisme sebagai paradigma baru dalam berteologi sekaligus menjadi isu global dan kontroversial.

Sebagaimana wacana pluralisme yang di uraikan di atas maka pluralisme muncul berkaitan dengan bagaimana sikap keagamaan dalam memaknai kebenaran agama lainnya. Selanjutnya timbul tiga sikap keagamaan yakni eksklusifisme, eksklusifisme dan pluralisme. Singkatnya pluralisme merupakan keadaan masyarakat yang majemuk (sistem sosial dan 
politik) dengan mentoleransi terhadap keragaman pemikiran, peradaban agama dan budaya. Tidak hanya sikap toleransi yang ditonjolkan tetapi juga mengakui kebenaran masing-masing pemahaman para pengikutnya atas klaim kebenaran.Persoalan klaim kebenaran menjadi penyebab lahirnya radikalisasi agama, perang dan penindasan atas Nama agama. Konflik antar umat beragama akan selesai jika masing-masing agama tidakmenganggap bahwa ajaran agama meraka paling benar. Menghilangkan keyakinan akan klaim kebenaranagama dan paham yang dianuta dalah Itulah tujuan akhirdari gerakan pluralisme.

\section{Pengertian Pluralisme Agama}

Pluralisme agama secara etimologi berasal dari dua kata, dalam bahasa inggris disebut religious pluralism. Dalam bahasa arab diterjemahkan al-ta'addudiyah al-diniyyah.Thoha (2005:11-12) mendefinisikan pluralisme agama yaitu koeksistensi berbagai kelompok atau keyakinan di satu waktu dengan tetap terpeliharanya perbedaan dan karakteristik agamaagama tersebut. Terdapat kesulitan ketika mendefinisikan agama yang diakui sebagai kesepakatan bersama. Untuk itu, terdapat tiga pendekatan dalam mendefinisikan agama yaitu segi fungsi, institusi dan substansi. Pendefinisian terebut sangat relatif tergantung latar belakang ahli. Ahli sejarah cenderung mendefinisikan agama sebagai suatu institusi historis, para ahli sosiologi dan antropologi mendefinisikan dari sudut fungsi sosialnya. Ahli teologi, fenomenologi dan sejarah melihat dari aspek substansinya sebagai sesuatu yang sakral. Secara hakikat, tiga pendekatan tersebut adalah saling menyempurnakan dan melengkapi jika pluralisme agama didefinisikan sesuai objektif di lapangan.

Sementara Madjid (1998) menyebut pluralisme agama adalah adanya tiga sikap dialog. Pertama, sikap eksklusif melihat agama-agama lain salah; kedua, sikap inklusif agama lain sebagai bentuk implisit dari agama yang kita anut; sikap pluralis yaitu agama-agama adalah jalan yang sama dalam mencapai kebenaran. Islam pada dasarnya bersifat inklusif dan merentangkan tafsirannya ke arah yang semakin pluralis karena pluralisme sebagai sunatullah yang abadi. Paradigma inklusif memberikan sikap toleran bagi pemeluk agama lain karena juga terdapat kebenaran dan jalan keselamatan meskipun tak sesempurna agama yang dianutnya (Misrawi,2007).

Sikap inklusivisme ini, senantiasa mencoba mencari common platform atau di antara berbagai keragaman baik dalam intra agamamaupun antar agama. Dengan kata lain, perbedaan merupakan sebuah keniscayaan,akan tetapi terdapat titik temu yang bisa dipertemukan di antara perbedaantersebut. Sikap inklusif ini memberikan pandangan di mana agama yang lurus adalah yang membawa pesankemanusiaan universal yang merupakan esensi dari inklusivisme. Dalam pangangan Madjid, ajaran Nabi Muhammad SAW membawa pesan kemanusiaan universal sekaligus memiliki potensi kuat membangun kalimatun sawa(prinsip yang sama) dengan agama lainnya karena ajaran yang dibawa oleh Nabi Muhammad SAW merupakan ajarantentang keterbukaan dan kerahmatan terhadap umat agama-agama di dunia. Yang harus dperhatikan dan dikembangkan yaitu sikap berbaik sangka terhadapkelompok lain, bukan sebaliknya. 


\section{Visi Islam dalam Pluralisme}

Berkaitan pembahasan pluralisme, Agama Islam sejak awal telah memperkenalkan prinsip-prinsip pluralisme, atau lebih tepatya pengakuanterhadap pluralitas dalam kehidupan manusia. Pengakuan Islam terhadap adanyapluralitas itu dapat dielaborasi (uraikan) ke dalam dua perspektif; pertama teologis dan yangkedua sosiologis.

a. Pandangan Islam terhadap Pluralitas Agama

Dalam persepektif teologi Islam tentang agama-agamakontemporer, pembahasan tentang agama-agama dan relasinya mengambilbentuk dalam ilmu perbandingan agamadiperkenalkan oleh almarhum Mukti Ali, mantan GuruBesar Ilmu Perbandingan Agama di IAIN Yogyakarta. Ali (1991) menciptakan suatu dialog positif antar agamaagama yang ada, terutama tiga agamabesar yaitu Yahudi, Nasrani dan Islam. Islam dalam Al-Qur'an telah disebutkan untuk menghormati agama lain dan melarang mencelanya. Firman Allah SWT Surah Al-An'am:

"Dan janganlah kamu memaki sembahan-sembahan yang mereka sembah selain Allah, karena mereka nanti akan memaki Allah dengan melampaui batas tanpa pengetahuan. Demikianlah Kami jadikan setiap umat menganggap baik pekerjaan mereka. Kemudian kepada Tuhan merekalah kembali mereka, lalu Dia memberitakan kepada mereka apa yang dahulu mereka kerjakan."(Q.S. Al-An 'am: 108)

Al-Qur'an sangat tegas mengakui keberadaan agama-agama lain danmenyerukan kepada umat Islam untuk hidup berdampingan secara damai. Namunperlu digaris bawahi di sini bahwa dengan mengakui keberadaan agama-agama lain,tidak berarti Islam membenarkan agama-agama itu. Harus dibedakan secara tegasantara mengakui dengan membenarkan.

Keyakinan kebenaran agama yang dipeluk adalah cermin keimananseseorang. Setiap pemeluk agama yang beriman tentu akan berpendapat bahwa agamanyalahyang paling benar. Hal semacam ini perlu dikritisi karena semua agama tentu menawarkan jalan keselamatan. Coward (1989) dalam Kristen,dikenal doktrin extra ecclesiam nulla salus-tidak ada keselamatandi luar Gereja- dan extra ecclesiam nullus propheta -tidak ada Nabi di luar Gereja-. Doktrin ini menunjukkan teologi eksklusif Agama Kristen di mana Kristen merasatidak ada gunanya mendengarkan suara-suara dari agama lain.Dalam konteks Islam, sikap eksklusif bisa ditemukan beberapa ayat 19dalam AlQur'an menunjukkan secara jelas sikap ini. Dalam Surah Ali Imran ayat 19, Allah SWT berfirman:

"Sesungguhnya agama (yang diridhai) di sisi Allah hanyalah Islam. Tiadaberselisih orang-orang yang telah diberi Al Kitab kecuali sesudah datang pengetahuan kepadamereka, karena kedengkian (yang ada) di antara mereka. Barangsiapa yang kafir terhadap ayat-ayat Allah maka sesungguhnya Allah sangat cepat hisab-Nyall. (QS. Ali Imran: 19). 
Terlepas dari eksklusifitas Islam, ajaran Agama Islam secara tegas mengajak umatnya untuk senantiasa menjaga hubungan baik dengan sesama manusia. Selama non muslim tidak mengganggu ibadah umat muslim,maka umat Islam dilarang untuk mengganggu pemeluk agama lain.

b. Pandangan Islam terhadap Pluralitas Sosial

Keanekaragaman suku, ras, adat istiadat dalam kehidupan manusia adalah takdir Allah SWT dimana dengan keberagaman tersebut manusia diajak untuk saling mengenal dan menghormati. Allah SWT berfirman:

"Hai manusia, sesungguhnya Kami menciptakan kamu dari seorang laki-laki danseorang perempuan dan menjadikan kamu berbangsa-bangsa dan bersuku-suku supaya kamu saling kenal mengenal. Sesungguhnya orang yang paling mulia di antara kamu di sisi Allah ialah orang yang paling bertakwa di antara kamu. Sesungguhnya Allah Maha Mengetahui lagi Maha Mengenal”. (QS. Al-Hujuraat: 13)

Semangat egalitarianisme dijunjung tinggi dalam surah tersebut. perbedaan antara laki-laki dan wanita tidak ada, yang ada hanyalah kualitas keimanannya pada Allah SWT. Ajaran inilah yang mengharuskan memiliki sikap persamaan (almusawwah) yaitu sikap tidakmembedakan umat manusia atas jenis kelamin, asal etnis dan warna kulit, latarbelakang, historis, ekonomi, sosial dan sebagainya. Sikap ini merupakanrefleksi dari sikap tauhid yang dimanifestasikan dalam ukhuwah yakni prinsip yang menekankan nilai kebersamaan dibingkai rasa tanggung jawabdalam menjalani kehidupan bermasyarakat.

Egalitarianisme Islam dalam pengertian luas berkaitan dengankeadilan, eksistensi, demokrasi dan persamaan, prinsip-prinsip musyawarah (demokrasi partisipatif), kebijaksanaan dan perwakilan. Selain itu, juga terkait dengankesadaran hukum bahwa tidak dibenarkanbertindak di luar hukum. Nabi dalam misi kepemimpinannya menerapkan egalitarianisme dan kesadaran hukum untuk mengembangkankomunitas negara yang konstitusional. Piagam Madinah, seperti konstitusikonstitusilainnya, adalah hasil kontrak sosial dan pengakuan semua anggotamasyarakat tanpa memandang latar belakang sosial mereka (Madjid,1989)..

Persatuan umat yang diusung tanpa memandang latar belakang karena seluruh umat di dunia adalah satu kesatuan berasal dari nenek moyang yaitu Adam dan Hawa (Q.S. An-Nisa). Islam adalah agama yang secara inheren mengusung semangategalitarianisme. Mengutip Gellner, Nurcholish Madjid (1989) mengatakan bahwa faktatentang beberapa varian Islam yang sentral, formal dan murni adalah egalitarian dan ilmiah. Sementara hirarki dan ekstasi adalah bentuk-bentuk pinggiran yangberkembang dengan maksud membantupenyesuaian diri kepada dunia modern.

\section{Pluralisme dalam Masyarakat Madani: Pemikiran M. Dawam Rahardjo}

Dawam Rahardjo merupakan tokoh intelektual yang memilikiperhatian besar terhadap wacana pluralisme dengan konsep civil society(masyarakat madani) yang jugamarak di Indonesia. Masyarakat madani menurut pemikiran Rahardjo memiliki dua esensi penting 
yaitu nilai-nilai kebajikan umum dan integrasi sosial. Rahardjo dalam Arifin (2009) menjelaskan masyarakat madani adalah masyarakat yang mengacu pada nilai kebajikan umum yang disebut al-khair. Masyarakat ini harus dipertahankan dengan membentuk persekutuan, perkumpulan, perhimpunan, dan sebagainya yang memiliki visi dan pedoman bertindak. Dasar utama dari masyarakat madani adalah integrasi sosial yang didasarkan pada pedoman hidup, menghidarkan diri dari konflik serta permusuhan yang berakibat perpecahan persaudaraan. Atas dasar ini masyarakat diperintahkan untuk membentuk perhimpunan dengan cita-cita kebajikan umum karena (Q.S. al-Imran: 104) menjelaskan " dan hendaklah ada di antara kamu segolongan umat yang menyeru kepada kebajikan umum (al-khair), menegakkan yang ma'ruf dan mencegah yang mungkar. Mereka itu adalah orang-orang yang mencapai kebahagiaan (al-falah).

Nilai kebajikan dan integrasi sosial inilah menurut Rahardjo merupakan inti dari piagam madinah pada zaman Nabi SAW. Prinsip-prinsip utama dalam piagam madinah yakni pertama pengakuan bahwa mereka bagian dari integrasi sosial yang disebut al-ummah. Kedua, mereka tunduk pada nilai-nilai luhur yang disebut al-khair (kebajikan)digunakan untuk menegakkan nilai keadilan, perdamaian, kesamaan dan kebebasanKetiga, mekanisme tersebut untuk menentukan tindakan yang baik dan yang buruk. Kebajikan dapat diwujudkan melalui perlindungan terhadap negara, terhadap jiwa dan harta, kebebasan beragama, keamanan, kepastian hukum dan musyawarah. Adapu hal yang perlu dicegah yaitu kekacauan, kezaliman, pengrusakan, pertikaian dan agresi dari luar (Arifin, 2009:86).

Dari pandagan ini Rahardjo menggunakan preferensi keagamaan untuk mengkonstruksi masyarakat madani. Sikap ini menunjukkna sikap yang positif-konstruktif terhadap peran agama. Agama di Indonesia dapat dijadikan faktor integratif masyarakat madani dalam menghindari konflik sosial. Berikut kutipan Arifin (2009:86) agama bisa merupakan konflik maupun harmonisasi menurut Rahardjo:

"Dalam masyarakat primitif, agama diciptakan untuk menyatukan individu dan membentuk masyarakat atas dasar solidaritas mekanis. Di sini agama menyatu dengan masyarakat. negara”. Apabila agama, sebagai sistem simbol dan sistem budaya goyah, maka masyarakat akan mengalami disintegrasi atau dalam kondisi konflik, karena agama adalah juga sistem sosial yang membentuk masyarakat. Atas dsar inilah teori modern 'mengahargai' dan mempertimbangkan agama sebagai faktor integratif. Karena itu, maka proses modernisasi dan perkembangan ekonomi yang menggoyahkan sendi-sendi agama ditangapi dengan sikap 'prihatin' oleh berbagai ahli ilmu sosial. Itulah agaknya yang memberi penjelasan, mengapa berbagai ilmu-ilmu sosial 'mempertimbangkan' kembali agama dan tujuan mengambil pelajaran mengapa dalam masyarakat primitif berfungsi positif sebagai faktor integratif. Pendekatan fungsional terhadap agama menghasilkan dua gagasan. Pertama, menciptakan substitusi agama dengan membentuk instituai-institusi yang mengandung solidaritas or ganis, misalnya institusi negara. Atau menempatkan posisi agama dan pada fungsinya yang dipandang tepat sebagai pemeliharaan pola-pola latin, dengan resiko, agama bisa merupakan kekuatan oposisi yang mengontrol perilaku".

Dalam kehidupan masyarakat modern saat ini, terdapat lembaga-lembaga substitusi agama berdasarkan logikasolidaritas organis. Negara merupakan jelmaan dalam mewujudkan 
solidaritas tersebut. Negara yang terbentuk ini turut memarginalisasi fungsi agama. Namun jika agama dalam negara benar-benar memiliki fondasi kuat maka agama tetap bertahan sebagai kekuatan latin dan merupakan sumber perubahan sosial. Untuk menjalankan fungsinya secara luas, agama menurut Rahardjo diperankan sebagai agama profetis. Agama profetis artinya agama yang tidak murni spiritual melainkan juga mengedepankan sosial dan politik sebagaimana peran agama zaman kenabian. Agama dalam negara memiliki dua bentuk: 1) bentuk kependetaan dimana agama memiliki peran lebih sebagai penyangga status quo dan memelihara integrasi melalui penyelenggaraan ritus-ritus. 2) agama bisa berperan sebagai kekuatan pembebas (agama profetis).

Agama dapat berperan secara profetis jika agama dirumuskan ke dalam suatu teologi yang responsif terhadap persoalan-persoalan konkret di masyarakat. Agama profetis mengarahkan kembali akar pemikiran yang paling fundamental(kebenaran, keadilan dankeindahan serta menyadari sisi kemanusiaannya). Acuan seperti ini menciptakan sikap kritis terhadaplingkungan dan alam fikiran yang mapan, termasukalam pikiran keagamaan sendiri. Kecenderungan seperti ini akan melahirkan teologikontekstual dan mengacu kepada pembaharuanmasyarakat. Dengan sendirinya, aliran ini memiliki resiko konflik perpecahan demi perubahan. Pada akhirnya teologi bercorak profetis memberikan tantangan pada agama kependetaan dalam menjaga status quo.Diakui peran agama profetis mengadung banyak resiko namun masih memiliki kemungkinan untuk berkembang asalkan tidak menjurus pada radikalisme "fundamentalisme" atau radikalisme "teologi pembebasan". Selanjutnya peran profetik membuka cakrawala melakukan dialog antar-iman dan berkehendak untuk melakukan komunikasi,karena telah mengambil sikap kritis terhadap apa yang mereka yakini selama ini. Peran diaolgis inilah membuka ruang selanjutnya bagi perumusan platform bersama yang lebih luas.

\section{Pluralisme dan Etika Sosial dalam Masyarakat Madani: Nur Cholish Madjid}

Istilah masyarakat madani sebagaimana yang dikemukakan oleh kelompok Nurcholish yang berarti masyarakat yang beradab, berakhlak mutlak, dan berbudi pekerti luhur. Dalam islam masyarakat madani merujuk kepada seluruh masyarakat baik itu individu, keluarga, maupunnegara, yang semuanya memiliki sifat dan budaya teras (berperadaban)

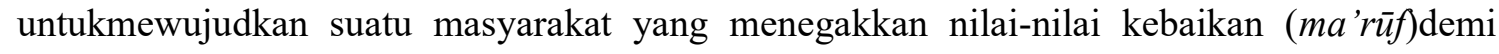
terbentuknya masyarakat yang beradab (tamaddūn). Model masyarakat idealdalam sejarah Islam ialah masyarakat dannegara Madinah. jika dalam masyarakat Barat, civil society akhirnya adalahdemokrasi yang lahir setelah proses sekularisasi. Masyarakat Islam, civil society (masyarakatmadani) dibentuk dengan landasan, motivasi, dan etos keagamaan. Dari sini, Madjid memberikan porsi lebih pada agama atau kriteria paling utama mayarakat madani (Madjid,2000).

Terdapat tiga tema besar rumusan masyarakat madani menurut Madjid.Pertama: demokrasi, kedua:masyarakat madani (civil society), dan ketiga: civility. Beliau berpandangan bahwa masyarakat madani adalah rumah bagi demokrasi dimana berbagai macam perserikatan, klub, gilda, sindikat,federasi, persatuan, partai dan kelompok bergabung untuk menjadi perisai antara negara dan warga negara Sedangkan civility merupakan kualitas etik masyarakat madani, seperti keterbukaan,toleransi, dan kebebasan yangbetanggung jawab. 
Madjid menyatakan bahwa kualitas masyarakat madani sangatditentukan oleh sejauh mana civility tersebut dimiliki warganya. Civilitymengandung makna toleransi, yang mempunyai arti kesediaan pribadi-pribadiuntuk menerima berbagai macam pandangan politik dan tingkah laku sosial, jugabersedia untuk menerima pandangan bahwa tidak selalu ada jawaban yang benaratas suatu masalah (Yasmadi,2005).

Peletakan fondasi agama dalam bernegara dalam mewujudkan masyarakat madani membutuhkan manusia-manusia yang berprinsip semangat ketuhanan, dengankonsekuensi berbuat baik kepada sesama manusia, dan juga dibutuhkan adanyaketerlibatan dan partisipasi dari seluruh lapisan masyarakat. Ciri-ciri masyarakat madani yakni egalitarianisme, keterbukaan, penegakan hukum dan keadilan, toleransi kemajemukan, dan musyawarah seperti telah dicontohkan Nabi SAW dalam memimpin umatnya.

\section{a. Egalitarianisme}

Madjid menyatakan faktor yang sangat fundamental dan dinamis dari etika sosial dalam ialah egalitarianisme. Perbedaan keimanan, warna kulit, ras, maupun status sosial atau ekonominya dianggap tidak ada. Semua dianggap sebagai partisipan yang sama dalam komunitas. Selanjutnya egalitarianisme Islam menyangkut rasa keadilan, keberadaan, kerakyatan dan persamaan, prinsip musyawarah (demokrasipartisipatif), hikmat (wisdom), dan rasa perwakilan (representativeness). Egalitarianisme diwujudkan oleh Nabi SAW. dalam rintisannya untuk membentukkomunitas negara yang berkonstitusi. Setiap konstitusi mengikat seluruhmasyarakat, dan harus ditaati dan dipatuhi dengan konsekuen sesuai denganperintah agama untuk menaati setiap perjanjian dan kesepakatan bersama.

b. Keterbukaan

Keterbukaan yaitu kesediaan menerima dan mengambil nilai-nilai(duniawi) yang mengandung kebenaran. Al-Quran memerintahkan bagi kaum Muslimuntuk mendengarkan pikiran-pikiran dan mengikuti mana yang palingbaik. Menurut Madjidkeadaan umat Islamsekarang ini lebih cenderung dan bersifat tertutup, berdada sempit dan sesak seperti orangyang terbang ke langit, dan itu merupakan salah satu tanda kesesatan. Sikap terbuka akan menumbuhkan kesadaran sesama manusia dan sesama makhluk untuk saling menghargai danmenghormati pada diri seseorang, berbentuk hubungan sosial yang salingmengingatkan tentang apa yang benar, tanpa memaksakan kehendak pribadi. Sikap terbuka untuk saling menghargai tidak lepas dari sikap kritis dapat dikatakan adanya petunjuk dari Tuhan karena rasa itu sejalan dengan rasa ketaqwaan.

c. Penegakan hukum dan keadilan

Keadilan dalam Al-Quran menurut Madjid dinyatakan dengan istilah'adl dan qisth. Pengertian adil juga terkait dengan sikapseimbang dan menengahi (fair dealing), dalam semangat moderniasasi dantoleransi, yang dinyatakan dengan istilah wasath (pertengahan). Sikap seimbang memberikan kesaksian dengan adil, karenadilakukan dengan pikiran tenang dan bebas dari sikap berlebihan, tidak bisa mementingkan diri 
sendiri, melainkan dengan pengetahuan yang tepatmengenai suatu persoalan dan mampu menawarkan keadilan (lihat Q.S. AnNisa:135).

Menegakkan keadilan sebenarnya juga merupakantanggung jawab bagi seluruh masyarakat dan badan-badan pemerintahan. Madjid menjelaskan bahwa dalam penegakan hukum dan keadilan, Nabi tidakpernah membedakan antara orang kaya dengan orang miskin, orang atas denganorang bawah. Nabi menegaskan bahwa bangsa-bangsa pada zamandahulu hancur karena jika orang atas berbuat kejahatan dibiarkan begitu saja, tetapijika orang bawah yang berbuat kesalahan maka akan dan pasti dihukum. Berikuthadis Nabi mengenai keadilan(HR.Bukhari) yang artinya: demi Dzat yang diriku berada di Tangan-Nya, kalau seandainya Fathimah bintu Muhammad mencuri, niscaya akan aku potong tangannya (Lathifah,2005).

d. Toleransi dan kemajemukan

Satu asas masyarakat madani (civil society) yang dicita-citakan oleh semua orang adalah toleransi. Indonesia, Sebagian besar masyarakatnyaberagama Islam, dan itu bisa disebut sebagai dukungan terhadap paham toleransi karena Islam telah melaksanakan pengalaman toleransi pada kehidupan nyata. Sebagai contoh bukti bahwa Islam menjadipanutan mayoritas, agama-agama lain tidak mengalamikesulitan berarti. Tapi jika kaum Muslim menjadi minoritas, mereka selalu mengalami kesulitan yang tidakkecil, kecuali di negara-negara demokratis barat karena memperoleh kebebasan beragama yang menjadi hak mereka.

Al-Quran (Q.S. Al-Maidah: 82) mengajarkan bahwa umat Islam harus menghormati semua pengikut kitab suci (Rachman,2011). Maka dari itu, Nabi SAW yang ditegaskan sebagai suri tauladan umat manusia memilikikepribadian yangsangat toleran kepada sesama manusia karena adanya rahmat Allah SWT. Pola hidup manusia menganut hukum Sunnatullāh tentangpluralitas, antara lain karena Allah SWT menetapkan jalan dan pedoman hidup yang berbeda untuk berbagai golonganmanusia. Perbedaan bukan dijadikan perselisihan danpermusuhan, melainkan pangkal tolak bagi perlombaan menuju kebaikan.

e. Musyawarah

Musyawarah selalu menjadi tema penting dalam setiappembicaraan tentang politik demokrasi, dan tidak dapat dipisahkan dari konseppolitik Islam. Madjid, musyawarah secara kebahasaan berarti saling memberi isyarat tentang apa yang baik dan apa yang benar sesuai ajaran agama untuk selalu berbuat kebenaran. Kebenaran sebagai syaratketiga keselamatan manusia, setelah syarat-syarat iman dan amal shaleh.Musyawarah adalah suatu proses pengambilankeputusan dalam masyarakat yang menyangkut kepentingan bersama. Sedangkan mufakat(muwāfaqah atau muwāfaqat) adalah disetujuinya keputusan yang diambil melalui musyawarah.

Musyawarah sebagai proses politik yaitu yang disebut dengan istilahpartisipasi, kebebasan, dan persamaan. musyawarah mustahil dijalankan tanpa kehadiran dari ketiga elemen tersebut. Tidak mungkin mengadakan musyawarah tanpa adanya kehadiran, baik secara langsung maupunsecara tidak langsung. 
Musyawarah juga tidak mungkin diwujudkan tanpa adanyakebebasan untuk menyatakan pendapat atau freedom of expression. Dan dalampengambilan keputusan dalam musyawarah dilandasi oleh kebebasan dan haruslahdidasari oleh semangat persamaan atau equality (Hidayat,1995). Kewajiban bermusyawarah diatur dalam QS. Ali-Imron:159 yang artinya Apabila "salah seorang di antara kamu meminta bermusyawarah dengan saudaranya, maka penuhilah"(HR. Ibnu Majjah).

Madjid menambahkan bahwa dalam masyarakat yang diatur oleh prinsipprinsipMusyawarah adalah mutlak atau tidak dapat ditawar-tawar yang menentukan tingkah laku manusia. Dalammusyawarah, setiap peserta harus tulus dan serius mendengarkan, memahami dan menghargai pendapat orang lain. Dan padaurutannya memberi pendapat dengan penuh ketulusan dan rasa hormat kepadapara pendengar. Jika terdapat perbedaan, maka yang harus dilakukan adalahmenunjukkan sikap hormat kepada sesama. Ini dilakukan untuk saling menghormati dan mengerti antar sesama, menciptakan mekanisme berpikir yang baik. Maka dengan begitu musyawarah akan mencapai tujuan yang sebaik-baiknya.

\section{Nalar pluralisme Agama Hick}

Menurut Hick tantangan keagamaan sekarang ini adalah pluralisme. Bukan berarti pluralisme merupakan tantangan satu-satunya, tetapi jika pluralime tidak diperhatikan dengan sungguh-sungguh agama akan kehilangan kebenaran tentang dunia dan masyarakat tempat mereka hidup. Jaringan komunikasi menembus batas-batas kelompok antar umat agama yang awalnya mengisolasi kelompok tersebut. Hipotesa pluralisme Hick berangkat dari tiga alasan. Pertama, kebanyakan orang secara intuitif memiliki satu tujuan yang sama. Kedua, pluralitas diwacanakan secara jelas dan persuasif. Ketiga, hipotesanya dapat merespon terhadap kegelisahan teologis keagamaan yang plural.

Hick dalam "pluralistichypothesis"menyatakan semua agama-agama secarakultural merupakan sebagai respon terhadap realitas puncak yang sama (Hick,1995). Berikut empat faktor kritis mengenai fenomena keagamaan:

1) Fakta setiap orang pada dasarnya adalah religious,

2) Hasil observasi terdapat perbedaan substansial yang tampak secara lahiriah dalam kepercayaan keberagamaan.

3) Asumsi bahwa kepercayaan keagamaan bukanlah ilusi.

4) Kesadaran bahwa hampir semua tradisi keagamaan secara positif mampu merubah pola hidup penganutnya.

Pembahasan bahwa kepercayaan bukanlah ilusi dapat dilihat dari pendekatan naturalisme dan absolutisme. Menurut naturalisme semua masalah keagamaan yang berhubungan dengan relitas puncak adalah palsu, Hick menolak pandangan ini. Lorens (1996:688) Naturalisme biasanya mengarah kepada pandangan filosofis yang memberikansuatu peranan menentukan atau bahkan suatu peranan eksklusif kepada alamdengan menekankan oposisinya terhadap roh atau tataadikrodat. Pendekatan absolutisme menyebut bahwahanya ada satu sistem kepercayaan keagamaan yang secara literal adalah 
benar sementara sistem kepercayaan yang lain adalah salah. Pendekatan ini Hick juga tidak sependapat. Hickmenyadari absolutisme bisa diterima padasatu tradisi tertentu, namun pada tingkat realitas keberagamaanyang kompleks tentu tidak akan menemukan relefansinya.

Problematika yang demikian Hick memberikan alternatif pemikiran, intinya keagamaan dapat ditempuh melalui berbagai pengalaman hakikat tersebut berada pada realitas paling utama (ultimate reality) bersifat transedental dari berbagai bentuk dan macamnya. Hick menerapkan konsep distingsi Imanuel Kant dalam memahami perbedaan fenomenakeagamaan antara the Real sebagai sesuatu yang eksis dan the Realsebagai hasil pemahaman dari pengalaman individu dalamtradisi tertentu. Oleh karena itu, terjadinya perbedaan persepsiseperti itu akibat tidak adanya akses secara langsung kepada the Real sehingga melahirkan konflik konsepsi terhadap the Real. Semua persepsi terhadapthe Real selalu melalui mediator yaitu tradisi keagamaan yang unik yang dalam istilah Hick disebutsebagai "konsep lensa " (conceptional lens).

Gambar 1 Analogi Prisma-Lensa Pluralisme John Hick (Said,2015)

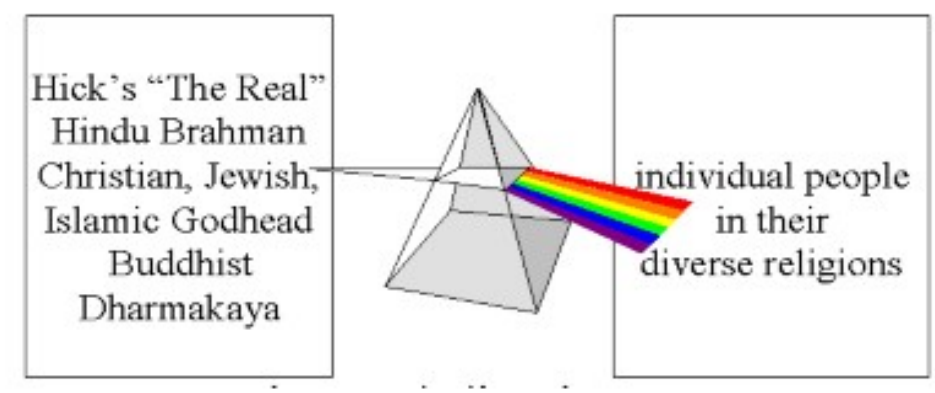

Ringkasan hipotesa pluralitas Hick dapat disimpulkan sebagai berikut: 1. Ada saturelitas ketuhanan, the Real, di mana sumber akhirnya adalahpengalaman keagamaan, 2 . Tidak ada tradisi keagamaan yangmemiliki persepsi secara langsung terhadap the Real, 3.Masing-masingtradisi keagamaan memiliki jalan yang benar menujukepada the Real, 4. The Real bersifat transenden dari berbagaipemahaman. Hick menilai pluralisme sebagai pandanganyang menyatakan bahwa perubahan hidup manusia dariketerpusatan pada diri sendiri menuju keterpusatan pada sangRealitas tunggal (Tuhan) terjadi pada semua agama melalui berbagai bentuk dan cara (Hick,1985)

\section{Modernisasi dan Pembangunan}

Menarik dibahas bahwa disintegrasi bangsa bermula dari konsep pembangunan yang kurang tepat. Dalam pembahasan ini penulis melihat modernisasi sebagai langkah awal munculnya berbagai masalah pembangunan. Untuk itu perlu dibedakan antara modernisasi dan pembangunan. Modernisasi menurut Dankwart A. Rustow identik dengan industrialisasi dimana kerja sama antar manusia menciptakan kontrol atas alam. Cyril E. Black mengungkapkan modernisasi adalah proses transformasi masyarakat akibat dari revolusi penggunaan ilmu dan teknologi. Agpalo (1992) menyebut ada dua faktor definisi modernisasi yaitu waktu dan pengetahuan. Faktor waktu berarti mengaitkan modernisasi jaman sekarang jauh lebih baik dari yang ada sebelumnya karena dianggap ketinggalan jaman. Sehingga yang 
dianggap baru pada ilmu dan teknologi harus diadopsi dalam ekonomi dan politik. Selanjutnya faktor pengetahuan dan teknologi berarti menujuk pada akumulasi iptek pada negara modern lebih banyak ketimbang negara yang belum modern.

Perbebedaan antara modernisasi dan pembangunan dapat dilihat pada proses industrialisasi. Industrialisasi merupakan pembangunan industri (perwujudan teknologi dan manajemen modern menitikberatkan efisiensi produksi) yang belum bisa disebut pembangunan karena hanya menguntungkan pemiliki modal sembari mengorbankan mayoritas rakyat untuk kepentingan industri. Belum cukup itu, kerusakan lingkungan dan menurunnya kualitas kehidupan turut disertakan. Pembangunan rumah mewah, pusat perbelanjaan, hotel dan lain-lain diklaim sebagai modernisasi kota tapi belum berdampak positif bagi seluruh warga kota tersebut. Modernisasi juga dianggap sebagai gejala developementalisme. Gelaja developmentalisme (Jemadu,2003) yakni pertama, pencapaian angka pertumbuhan ekonomi mengabaikan angka pemerataan (kesejangan bertambah) dan keadilan sosial. Kedua, pembangunan mengorbankan pelestarian lingkungan hidup (eksploitasi sumberdaya alam). Ketiga, hak sipil dan hak politik rakyat dikorbankan demi stabilitas politik negara. Keempat, berkembangnya mental suka menghutang (utang luar negeri) sebagai dana pembangunan infrastruktur. Kelima, korupsi semakin menjadi karena kolusi antara pengusaha dan penguasa untuk pertumbuhan ekonomi. Keenam, hilangnya kreatifitas dan inisiatif bangsa untuk pembangunan yang bersifat mandiri. Ketujuh, konflik sosial cenderung menggunakan pendekatan keamanan bagi upaya yang menghalangi pembangunan nasional dan mengganggu stabilitas nasional.

Modernisasi yang demikian ini oleh Agpalo (1992) harus diimbangi dengan proses civilization. Proses ini berupa transformasi situasi barbarisme (dominasi kaya atas miskin, kota atas desa, modern atas tradisional) menjadi situasi pembangunan politik. Adapun indikator pembangunan politik ini yaitu tegaknya hukum, civility atau rasa kebersamaan membela kepentingan umum dan keadilan sosial. Yang masih dicapai oleh Indonesia saat ini masih pada tahap modernisasi politik menjurus pada penciptaan lembaga-lembaga politik modern (partai politik) dan pemilihan umum. Ironisnya tujuan tersebut hanya untuk kepentingan kelompoknya kemudian menciptakan elitisme politik. Sebaliknya pembangunan politik dilakukan untuk meningkatkan indikator demokrasi: kontrol dari masyarakat pada setiap kebijakan publik dan kesetaraan tanpa membedakan suku, agama, ras, status sosial dan ekonomi. Keadilan sosial hanya terwujud apabila seluruh warga masyarakat memiliki akses yang sama terhadap pemenuhan kebutuhan dasar hidup layak.

Korten (1990) menyatakan model pembangunan ekonomi berpusat pada pertumbuhan ekonomi bukan solusi yang tepat karena menambah angka kesenjangan si kaya dan si miskin. Lebih lanjut tiga unsur pokok dalam krisis global: kemiskinan, kerusakan lingkungan dan kekerasan komunal. Senada dengan kritikan Rahardjo (2012) bahwa modernisasi pembangunan lebih menekankan eksploitasi alam ketimbang membangun manusia mandiri. Modernisasi tersebut membuang tradisi pengetahuan dan kearifan lokal yang menjadi simbol peradaban Indonesia dan lebih mengancam kelestarian lingkungan dan merusak ekosistem. Pada gilirannya, modernisasi pembangunan berdampak pada marginalisasi usaha ekonomi. Berikut disajikan konflik yang terjadi di Indonesia (menurut UU No.7/2012) kurun waktu Januari s.d April 2013-2015: 
Tabel 1. Konflik di Indonesia 2013 s.d 2015

\begin{tabular}{|c|c|c|}
\hline Tahun 2013 & Tahun 2014 & Tahun 2015 \\
\hline \multicolumn{3}{|c|}{ Berdasarkan sumber konflikUU No.7/2012 } \\
\hline $\begin{array}{l}\text { poleksosbud } 71 \text { kasus } \\
\text { Perseteruan SARA } 8 \text { kasus } \\
\text { Sengketa SDA/Lahan } 13 \\
\text { kasus }\end{array}$ & $\begin{array}{l}\text { poleksosbud } 68 \text { kasus } \\
\text { perseteruan SARA } 1 \text { kasus } \\
\text { Sengketa SDA/Lahan } 14 \\
\text { kasus }\end{array}$ & $\begin{array}{l}\text { poleksosbud } 20 \text { kasus } \\
\text { perseteruan SARA nol } \\
\text { sengketa SDA/Lahan } \\
\text { berjumlah } 6 \text { kasus }\end{array}$ \\
\hline Tahun 2013 & Tahun 2014 & Tahun 2015 \\
\hline \multicolumn{3}{|c|}{ Berdasarkan isu/pola konflik } \\
\hline $\begin{array}{l}\text { bentrok antar warga } 37 \text { kasus } \\
\text { Isu keamanan } 16 \text { kasus } \\
\text { Isu SARA } 9 \text { kasus } \\
\text { konflik kesenjangan sosial } 2 \\
\text { kasus } \\
\text { konflik institusi pendidikan } 2 \\
\text { kasus } \\
\text { konflik ORMAS } 6 \text { kasus } \\
\text { sengketa lahan } 11 \text { kasus } \\
\text { ekses politik } 9 \text { kasus }\end{array}$ & $\begin{array}{l}\text { bentrok antar warga } 40 \text { kasus } \\
\text { Isu keamanan } 20 \text { kasus } \\
\text { Isu SARA } 1 \text { kasus } \\
\text { konflik ORMAS } 3 \text { kasus } \\
\text { sengketa lahan } 14 \text { kasus } \\
\text { ekses politik } 4 \text { kasus }\end{array}$ & $\begin{array}{l}\text { bentrok antar warga } 8 \text { kasus } \\
\text { Isu keamanan } 9 \text { kasus } \\
\text { Isu SARA } 9 \text { kasus } \\
\text { konflik ORMAS } 1 \text { kasus } \\
\text { sengketa lahan } 6 \text { kasus } \\
\text { ekses politik } 2 \text { kasus }\end{array}$ \\
\hline
\end{tabular}

Sumber: Baderi (2017)

Penambahan jumlah konflik horizontal masih memungkinkan mengingat pada tahun 2016 hingga 2018 ini masih marak terjadi konflik horizontal. Korten (1990) menegaskan semakin mengejar pertumbuhan ekonomi maka semakin terancam pula integrasi sosial dalam masyarakat dan tidak tercipta lagi komunitas kemanusiaan. Sebagai contoh, keterpurukan tersebut dapat dilihat dalam perhitungan pertumbuhan ekonomi yang memasukkan biaya pengobatan kanker akibat polusi zat kimia masuh dalam angka GNP. Jika memang pertumbuhan ekonomi merupakan solusi, seharusnya kemiskinan tidak meluas, kerusakan lingkungan semakin parah dan disintegrasi sosial.

Untuk itu sejumlah alternatif ditawarkan dalam mengatasi krisis pembangunan ini. Rao (2003) menyarankan pertama, pengurangan atau penghapusan utang luar negeri sangat urgent untuk dilakukan. Kemampuan finansial Indonesia sebagian besar digunakan untuk membayar cicilan hutang daripada untuk menutup defisit APBN. Tuntutan ini cukup adil 
karena sebagiandari utang luar negeri dikorupsi oleh pejabat. Kedua, melalui public investment dalam bidang pertaniandan sektor informal karena dua sektor ini adalah konsentrasi penduduk miskin. Selainitu, investasi di bidang usaha kecil dan menengah juga perlu mendapat prioritas. Sumber dana utama untuk keperluan investasi publik ini adalah optimalisasi pemungutan pajakyang selama ini masih belum optimal. Ketiga, Indonesia perlumemfasilitasi industri-industri yang bersifat strategis dan berpeluang untuk kepentingan eksporsehinggamampubersaingdi pasarglobal.

\section{Membumikan Universalitas Agama dan Etika Melalui Pendidikan Tinggi}

Cerminan pendidikan agama pada sekolah-sekolah di Indonesia mulai dari sekolah dasar hingga tingkat perguruan tinggi dapat dikatakan monoteologi. Sangatlah maklum apabila lembaga atau yayasan tertentu yang bernaung pada suatu agama maka pendidikan agama yang diajarkan didominasi oleh ajaran agama yang dianut oleh lembaga tersebut. Dalam perkembangaannya agama menjadi sebuah kontestasi ajaran agama selain sebagai sosialisasi nilai-nilai. Kontestasi pertama berlangsung antara intern agama dan kontestasi kedua berlangsung antaragama. Kecenderungan agama sebagai keyakinan sangat dianjurkan dan diwajibkan. Keyakinan ini dapat dijadikan instrumen politik (regulasi) untuk memberikan sanksi jika tidak mematuhinya. Namun, disisi lain pengetahuan dan keberadaan agama lain diabaikan, agama lain dianggap buruk bahkan jarang mendapat tempat untuk diskusi dimana timbul klaim kebenaran terhadap agama sendiri semakin menguat.

Secara substansi ajaran agama memang mengandung unsur toleransi akan tetapi porsinya sangat kecil. Pengajarannya yang dangkal menekankan pada ritual, hafalan, istilah, doktrin dan konsep teologi saja. Hal semacam ini membuat pelajaran toleransi menjadi hilang maknanya lanjut pada aspek agama seperti hilang ditelan bumi. Sudah sangat umum jika agama Islam diajar oleh guru/dosen beragama Islam, agama Kristen/Katolik diajar oleh guru/dosen beragama yang beragama Kristen/Katolik, agama Hindu/Budha diampu oleh pengajar yang linier di agama tersebut. Dengan begitu agama-agama menjadi terkotak-kotak. Dari sinilah pengetahuan mengenal dan memahami agama lainnya menjadi penting. Perlu ditekankan terlebih dahulu bahwa mengenal bukan berarti percaya dan memahami bukan berarti menerima.

Terdapat ketakutan jika mengenal dan memahami agama lain maka dikhawatirkan akan berpindah agama. Tujuan mengenal dan agama lain tidak lain adalah mengurangi prasangka buruk agama lain dan menambah rasa hormat terhadap agama yang dikenalkan. Untuk mempertimbangkan rasa kekhawatiran tersebut, perguruan tinggi dinilai memiliki porsi yang tepat sebagai langkah kompromi dan realistis. Dengan status "maha" pada peserta didik, diharapkan kekhawatiran seperti yang telah dikemukakan di atas semestinya tidak terjadi lagi. Perguruan tinggi adalah kaum cendikiawan yang memiliki kedewasaan intelektual untuk memandang, menimbang dan menilai secara matang terhadap suatu peristiwa atau kejadian. Noor (2015) mengutarakan bahwa tidak relevan lagi apabila perguruan tinggi hanya mengajarkan pendidikan bagi agamanya sendiri. Sudah sekian lama pendidikan intra agama diperkenalkan mulai tingkat dasar hingga menengah atas. Oleh karena itu hendaknya perguruan tinggi mulai memperkenalkan tentang sejarah, ajaran dan spiritualitas berbagai agama di dunia. Sekali lagi bukan untuk dipercaya dan diterima. Pengetahuan tersebut dalam 
rangka memahami dan mengapresiasi. Kedewasaan seseorang dapat diperoleh jika telah melangkah jauh dan mengalami banyak kejadian. Pun dengan kedewasaan beragama bisa diperoleh jika seseorang telah mengenal dan mengapresiasi berbagai ajaran agama.

Pendidikan agama-agama juga mendorong mahasiswa untuk berpikir kritis. Mahasiswa dituntut melihat dunia dalam perpektif yang lebih luas bukan hanya berasal dari agama dan budayanya sendiri serta mempertimbangkan konsekuensi dan standar yang lebih luas pula. Pendidikan agama merupakan bagian dari pendidikan multikultur dan bukan dianggap sebagai angin lalu saja. Pendidikan agama-agama harus menjadi bagian dari kurikulum wajib di seluruh perguruan tinggi. Dengan begitu setiap mahasiswa mengenal beragam ajaran agama di dunia mulai dari Islam, Kristen/katolik, Hindu, Budha, Konguchu, dan mungkin agama-agama lokal.Selain pendidikan agama-agama, pendidikan etika adalah pelengkap pendidikan agama yang saling melengkapi. Bukankan agama telah mengajarkan moral baik dan moral buruk?. Sekilas, moral dan etika memiliki makna yang sama yakni acuan baik buruknya perbuatan. Dua kata tersebut sebenarnya dapat dibedakan.

Noor (2015:35), moral dalam agama diartikan sebagai motivasi dan inspirasi bagi penganutnya sebagai pedoman hidup. sedangkan etika merupakan argumentasi rasional yang memiliki dampak sosial, budaya dan politik. Etika lebih menekankan peran manusia dalam menjalani kehidupan yang beragam dan mengatasi permasalahan kehidupan secara etis.Noor menyebut kehidupan etis dalam modernitas saat ini memiliki tiga ciri. Pertama, kemajuan teknologi, komunikasi dan migrasi menyatukan umat manusia dengan latarbelakang budaya, agama, warna kulit, bahasa tentunya berbeda. Nilai-nilai yang dibawa teknologi masuk pada pemikiran per individu yang patut menjadi perhatian etika. Kedua, permasalahan etika baru yang melampaui batas ajaran agama-agama secara umum seperti bayi tabung, pemanasan global, kapitalisme hak perempuan, kaum gay adalah contoh masalah etis yang memerlukan refleksi filosofis secara mendalam. Ketiga, muncul sikap kepedulian etis universal yang ditimbulkan dari permasalahan etika di berbagai belahan dunia seperti pernyataan, konvensi, ratifikasi dan deklarasi berikut dengan solusinya. Inilah yang mendorong etika harus mengglobal dan universal dan kita kenal sebagai etika global atau etika universal. Dengan demikian etika sebagai pelengkap pendidikan agama dipandang perlu karena sudut pandang agama berbeda dengan sudut pandang etis. Diakui pula bahwa agama bisa menjadi fondasi etika atas permasalahan yang terjadi.

\section{Kesimpulan}

Pluralitas dalam beragama disikapi dengan kritis melalui pemikiran Dawan Rahardjo tentang civil society (masyarakat madani) yakni keberagaman agama merupakan refleksi nilai-nilai kebajikan umum dan intergrasi sosial. Civil society memiliki unsur nilai kabajikan umum dan integrasi sosial dijadikan dasar dalam berkehidupan untuk menghidari perpecahan antar umat beragama. Pemikiran Nur Colish Madjid juga selaras dengan Dawam bahwa pluralisme dibangun dengan tiga unsur yakni demokrasi, masyarakat madani (civil society) dan etika (civility). Gagasan Madjid bahwa masyarakat madani adalah rumah demokrasi sedangkan etika merupakan kualitas dari masyarakat yang terbuka, toleran dan kebebasan yang bertanggungjawab. Hipotesa Hick tentang pluralitas bahwa ada satu relitas ketuhanan, 
tidak ada persepsi secara langsung terhadap tuhan, setiap agama memiliki jalan yang benar dan puncaknya bersifat transenden.

Pemikiran tersebut pada intinya merujuk pada perlunya pemahaman terhadap keberagaman tanpa adanya perpecahan karena setiap agama pada dasarnya memiliki tujuan kebenaran. Perpecahan yang memicu sikap intoleran dan radikalisme justru datang dari ketidakadilan ekonomi akibat modernisasi pembanguan bercorak pertumbuhan ekonomi. Modernitas inilah yang merusak nilai kearifan lokal agama-agama. Sebaliknya pembangunan dilakukan untuk meningkatkan indikator demokrasi: kontrol dari masyarakat pada setiap kebijakan publik dan kesetaraan tanpa membedakan suku, agama, ras, status sosial dan ekonomi. Oleh karena itu, pendidikan agama-agama dan etika pada perguruan tinggi dinilai penting karena pada lembaga ini potensi menciptakan pemikiran yang progresif bisa dikompromikan demi menciptakan gagasan dan konsep yang jernih yang mengutamakan persatuan dan keadilan umat manusia dari aspek politik, budaya dan ekonomi. 


\section{DAFTAR PUSTAKA}

Abdullah, M. Amin. 1995. Studi Agama: Normatifitas atau Historisitas?. Yogyakarta, Pustaka Pelajar.

Agpalo, R.E. 1992. Modernization, Development, and Civilization: Reflections on the Prospects of Political Systems in the First, Second, and Third Worlds" Washington: Taylor and Francis.

Akbar, M. 2017. Analisis Penegakan Hukum Tindak Pidana Penistaan Agama (Studi Surat Edaran Kapolri Se/06/X/2015). Jurnal. Universitas lampung.

Ali, A. Mukti. 1993. Ilmu Perbandingan Agama di Indonesia. Bandung, Mizan. . 1991. Ilmu Perbandingan Agama. Yogyakarta: Tiara Wacana.

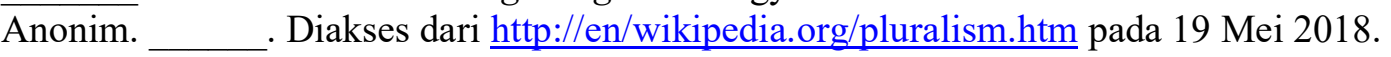

Arifin, S. 2009. Konstruksi wacana prlurasime di Indonesia. Jurnal HUMANITY Volume V, Nomor 1, $(80-92)$

Badan Pusat Satatistik. 2018. Ketimpangan Bisa Memicu Konflik dan Terorisme . diakses dari https://kumparan.com/@kumparanbisnis/bps-ketimpangan-pendapatan-bisa-memicukonflik-dan-terorisme pada 15 mei 2018

Baderi. F. 2017. Menyimak Konflik Sosial di Indonesia. Diakses dari http://www.neraca.co.id/ article/81045/menyimak-konflik-sosial-di-indonesiapada 29 Mei 2018

Coward, H. 1989. Pluralisme: Tantangan Bagi Agama-Agama. Yogyakarta: Kanisius. Madjid, N. 1989. Islam Kemodernan dan Keindonesiaan. Bandung: Mizan.

Darmaputera, E. 1987. Peranan Agama-Agama dan Kepercayaan Terhadap Tuhan Yang Maha Esa dalam Negara Pancasila yang Membangun. Jakarta: BPK. Gunung Mulia.

Esack, F. 1997. Membebaskan Yang Tertindas, Al-Quran, Liberalism Pluralisme. Bandung, mizan

Hick, J., A. 1995. Christian Theology of Religion, Kentucky, The Rainbow of Faith, . 1995. Christian Theology of Religion. Kentucky, The Rainbow of Faith. 1985. Problems of Religious Pluralism. New York: St. Martin's Press.

Hidayat, K, dkk. 1995. 70 Tahun Prof. Dr. Munawir Sjadzali. Jakarta: Paramadina.

Korten, D, C. 1990. Getting to the 21st Century: Voluntary Action and the Global Agenda. Hartworth: Kumarian Press.

Lathifah E. 2005. Ringkasan Shahih Muslim. Terjemahan. Jakarta: Gema Insani Press.

Lorens, B. 1996. Kamus Filsafat. Jakarta, Gramedia Pustaka Utama.

Madjid, N. 1998. Mencari Akar-Akar Islam bagi Pluralisme Modern: Pengalaman Indonesia dalam Jalan Baru Islam. Bandung: Mizan.

. 2000. Kehampaan Spiritual Masyarakat Modern: Respon Transpormasi Nilai-Nilai Islam Menuju Masyarakat Madani. Jakarta: Mediacita.

Misrawi, Z. 2007. Al-Qur'an Kitab Toleransi: Inklusivisme, Pluralisme, dan Multikulturalisme. Jakarta: Fitrah..

Noor, N,. M. 2015. Manual etika lintas agama untuk indonesia. Geneva: Globethics.net,

Rachman, B.,M. 2011. Ensiklopedi Nurcholish Madjid, Jilid 4. Jakarta: Mizan.

Rahardjo, M,.D. 2012. Pembangunan Pasca modernis: Esai-Esai Ekonomi Politik. Jogjakarta: Insist.

Rao, J.,M. 2003 Globalization, Debt and Development: Lessons and Policy Alternatives Facing Indonesia, in INFID, Creating Alternatives for Indonesia. Jakarta: International NGO Forum on Indonesian Development.

Rosyid, M. 2014. Keselarasan Hidup Beda Agama dan Aliran: Interaksi Nahdliyin, Kristiani, Buddhis, dan Ahmadi di Kudus. Fikrah, Vol. 2, No. 1 (75-94) diakses dari https://media.neliti.com/media/publications/61931-ID-keselarasan-hidup-beda-agamadan-aliran.pdf pada 11 mei 2018 
Said, N. 2005. Perempuan dalam Teologi dan HAM di Indonesia. Yogyakarta: Pilar Media. Sumandoyo, A. 2015. Konflik Aceh dan Papua Hanya Masalah Ekonomi Saja. Diakses dari https://www.merdeka.com/khas/konflik-aceh-dan-papua-hanya-masalah-ekonomi-sajawawancara-asad-said-ali-1.html pada 14 Mei 2018

Syamsuddin, A. 2010. Pluralisme di Indonesia: Paham dan Amalan. Diakses dari http://muafakatmalaysia.com/tag/johnhick/\# ftn1 pada 19 Mei 2018

Thoha A.,M. 2005. Tren Pluralisme Agama: Tinjauan Kritis. Depok: Perspektif.

Yasmadi. 2005. Modernisasi Pesantren. Ciputat: Ciputat Press.

Zuhdi, M., H. . Pluralisme dalam Perspektif Islam. IAIN Mataran. 